\title{
初回治療に喉頭機能温存手術を施行した局所進行喉頭癌の治療成績
}

\author{
松 居 秀 敏 ${ }^{1)}$. 岩 江 信 法 ${ }^{1)}$. 平 山裕 次 ${ }^{1)}$ ·米 澤 宏一郎 ${ }^{1)}$ \\ 林拓 二 ${ }^{1)}$. 蓼 原 瞬 ${ }^{1)} \cdot$ 嘉 村 陽 子 ${ }^{2)}$
}

\section{Oncologic Outcome of Organ-Preservation Surgery in Locally Advanced Laryngeal Squamous Cell Carcinoma}

\author{
Hidetoshi Matsui ${ }^{1)}$, Shigemichi Iwae ${ }^{1)}$, Yuji Hirayama ${ }^{1)}$, Koichiro Yonezawa ${ }^{1)}$ \\ Takuji Hayashi ${ }^{1)}$, Shun Tatehara ${ }^{1)}$ and Yoko Kamura ${ }^{2)}$
}

\begin{abstract}
Chemoradiotherapy has become the most popular in modality of laryngeal preservation treatment for patients with locally advanced laryngeal cancer. However, larynx-preservation surgery is only an option in select patients with T3-4a laryngeal cancer, and it may be able to achieve organ-preservation without chemoradiotherapy. In this study, we reviewed the medical records of 13 patients with locally advanced laryngeal squamous cell carcinoma who were primarily treated with organ-preservation surgery. We defined organ-preservation as (1) local relapse-free, (2) survival, (3) eating a regular diet, (4) no requirement for a feeding tube and (5) decannulation in this report. The 3-year overall survival rates were 100\% for cT 3, 75\% for cT 4 a and $92 \%$ for all. None of the patients experienced any local recurrences, and the 3-year locoregional control rates were $78 \%$ for T 3, 100\% for T 4 and 84\% for all. The 3-year organ-preservation rates were $89 \%$ for T3, 50\% for T 4 and $76 \%$ for all. The 3 -year radiotherapy-avoidance rates were $56 \%$ for T $3,0 \%$ for T 4 and $38 \%$ for all. Larynxpreservation surgery can produce a substantial local control and organ-preservation rate in locally advanced laryngeal cancers. Additionally, in select T3 laryngeal cancers, it can achieve both organ-preservation and radiotherapy-avoidance.
\end{abstract}

Key words : laryngeal cancer, larynx, organ-preservation, advance, surgery

\section{は じめに}

局所進行喉頭癌に対する標準治療は喉頭全摘出術と考え られる ${ }^{1)}$ ，そのため喉頭全摘出術拒否例に対する喉頭温存 治療は喉頭機能温存手術か化学放射線療法 (CRT) となる が, 局所進行例に対する喉頭機能温存手術は適応が限局さ れていることもあり, 現在はCRTが中心となっている2). この背景には喉頭温存を目的として進行喉頭癌に対して海 外で行われたランダム化比較試験による複数の報告 ${ }^{3,4)}$ の 存在がある。しかし, 近年 CRT 症例の増加に伴い, 喉頭 癌の治療成績の低下が報告されている ${ }^{5)}$ 。またこれらのラ ンダム化比較試験の長期経過報告で, CRTは重篤な晚期

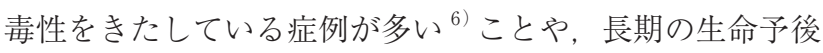
が必ずしも満足行く結果ではない7 ことが判明してきてい る。したがって, 生命予後のみならず QOLを含めた喉頭 温存治療の質の向上や治療選択肢の多様化は, 局所進行喉 頭癌治療に扔ける課題と考えられる。
実臨床に㧍いては, T3 症例の一部, あるいはCRTでは 制御困難と推測される $\mathrm{T} 4 \mathrm{a}$ 症例の一部に, 喉頭亜全摘出 術等による喉頭機能温存手術が適応できると考えられる症 例が少なからず存在する. 特に T 3 症例では, 根治手術に より局所頸部に対する化学放射線治療を回避した機能温存 が期待できると推測される，今回われわれは，局所進行喉 頭癌に対し初回治療として喉頭機能温存手術を施行した症 例における生存率と原発巣頸部制御率と喉頭機能温存率と 放射線治療温存率について検討したので報告する.

\section{対象}

2005 年から 2013 年の間に当院で初回治療として根治治 療を行った局所進行 (T3-4) 喉頭扁平上皮癌 65 例中, 喉 頭機能温存手術を施行した 13 例を対象とした。観察期間 は 12 ケ月か 115 ヶ月で中央值は 35 ヶ月であった。患者 背景は男性／女性が 12 例／1例，年齢は 43 歳から 65 歳 (中央值 58 歳), 病変の亜部位は声門上癌／声門癌が 11

1) 兵庫県立がんセンター頭頸部外科

2) 兵庫県立がんセンターリハビリテーション科

1) Department of Head and Neck Surgery, Hyogo Cancer Center

2) Department of Rehabilitation, Hyogo Cancer Center 
例 $/ 2$ 例, 原発巣進行度は $\mathrm{T} 3 / \mathrm{T} 4 \mathrm{a}$ が 9 例 $/ 4$ 例, N0/ $\mathrm{N} 1 / \mathrm{N} 2 \mathrm{~b} / \mathrm{N} 2 \mathrm{c}$ がそれぞれ 10 例 $/ 1$ 例 $/ 1$ 例 $/ 1$ 例で あった，術式は喉頭垂直部分切除術／喉頭亜全摘出術／拡 大喉頭亜全摘出術がそれぞれ 1 例 $/ 8$ 例 $/ 4$ 例であった (表 1).

治療の選択基準について以下に述べる。原則として喉頭 全摘出術の説明をした上で, 喉頭温存希望者にはCRTあ るいは喉頭機能温存手術を施行している，CRTについて はシスプラチン $100 \mathrm{mg} / \mathrm{m}^{2}$ を 3 週毎に 3 回同時併用を基 本としている，喉頭機能温存手術については輪状軟骨板と

表 1 患者背景

\begin{tabular}{ccllll}
\hline \hline 症例 & 年齢/性 & 亚部位 & $\mathrm{T}$ & $\mathrm{N}$ & \multicolumn{1}{c}{ 術式 } \\
\hline 1 & $43 \mathrm{M}$ & 声門 & 3 & 0 & VPL \\
2 & $58 \mathrm{M}$ & 声門上 & 3 & 0 & SCL-CHEP \\
3 & $61 \mathrm{M}$ & 声門上 & 3 & 0 & SCL-CHEP \\
4 & $62 \mathrm{M}$ & 声門上 & 3 & 0 & SCL-CHEP \\
5 & $62 \mathrm{M}$ & 声門上 & 3 & 0 & SCL-CHEP \\
6 & $65 \mathrm{M}$ & 声門上 & 3 & 0 & SCL-CHEP \\
7 & $65 \mathrm{M}$ & 声門 & 3 & 0 & SCL-CHEP \\
8 & $44 \mathrm{M}$ & 声門上 & 3 & 1 & SCL-CHP \\
9 & $55 \mathrm{M}$ & 声門上 & 3 & $2 \mathrm{~b}$ & SCL-CHEP \\
10 & $53 \mathrm{M}$ & 声門上 & $4 \mathrm{a}$ & 0 & ESCL-CHEP \\
11 & $57 \mathrm{~F}$ & 声門上 & $4 \mathrm{a}$ & 0 & ESCL-TCHEP \\
12 & $58 \mathrm{M}$ & 声門上 & $4 \mathrm{a}$ & 0 & ESCL-CHEP \\
13 & $46 \mathrm{M}$ & 声門上 & $4 \mathrm{a}$ & $2 \mathrm{c}$ & ESCL-CHP \\
\hline
\end{tabular}

M, male; F, female; VPL, vertical partial laryngectomy; SCL, supracricoid laryngectomy; ESCL, extended supracricoid laryngectomy; CHEP, cricohyoidoepiglottopexy; CHP, cricohyoidopexy; TCHEP, tracheocricohyoidoepiglottopexy
一側の披裂が温存可能と思われる場合に対象としたが非常 に限局した適応となる ${ }^{8)}$. 頸部郭清の併施については術前 にリンパ節転移ありと診断した症例に施行している.

\section{方法}

3 年粗生存率, 3 年原発巣頸部制御率, 3 年喉頭機能温 存率, 3 年放射線治療温存率について Kaplan-Meier 法で計 算した. 2 群間の比較は log-rank検定を使用し, $p<0.05$ を有意差ありとして扱った。統計解析ソフトは $\mathrm{GraphPad}$ Prism 6 (GraphPad Software Inc., San Diego, CA) を使用 した，粗生存率の計算の際には，全死因による死亡をイべ ントとした。原発巣頸部制御率の計算の際には, 原発巣, 頸部いずれかの再発をイベントとした，喉頭機能温存の定 義として原発巣無再発, 生存, 普通食摂取が可能で補助栄 養が不要，気管切開孔の開存なしのいずれも満たすことと した。喉頭機能温存率の計算の際には原発巣再発，全死因 による死亡, 普通食摂取不能, 気管切開孔の開存をイベン トとした。術後一時的な嚥下障害や気道狭窄が生じること を考慮し, 喉頭機能温存手術後 3 ケ月時点での食事内容と 気管切開孔の状態の初回判定を行った，手術で原発巣が断 端 $5 \mathrm{~mm}$ 以内のマージン (近接), もしくは断端陽性, 頸部 リンパ節に節外浸潤ありの症例には術後CRTを施行して おり，CRTが不要であることを放射線治療温存と定義し た。放射線治療温存率の計算の際には照射開始をイベント とした

\section{結果}

結果の一覧を表 2 に示す.

1 治療成績について

全例に原発巣再発を認めなかった， 3 例に頸部リンパ節 再発をきたし，頸部郭清後にCRTを施行していた。 それ により 2 例（症例 5,8）は非担癌生存となっていたが, 残

表 2 術後経過一覧

\begin{tabular}{clcll}
\hline \hline 症例 & 食事内容 & 気管孔 & 術後照射 & \multicolumn{1}{c}{ 術後予後 } \\
\hline 1 & 普通食 & - & - & 無再発生存 \\
2 & 普通食 & - & - & 無再発生存 \\
3 & 普通食 & - & - & 無再発生存 \\
4 & 経口摂取不可 & 喉頭全摘出 & - & 無再発生存 \\
5 & 普通食 & - & - & 頸部再発, 非担癌生存 \\
6 & 普通食 & - & - & 無再発生存 \\
7 & 胃瘻併用 & - & - & 頸部再発, 肺転移死 \\
8 & 普通食 & - & 断端近接 & 頸部再発, 非担癌生存 \\
9 & 普通食 & - & 断端近接 & 無再発生存 \\
10 & 普通食 & - & 断端近接 & 無再発生存 \\
11 & 普通食 & 断端近接 & 無再発生存 \\
12 & 胃瘻併用 & レティナ & 断端陽性 & 無再発生存 \\
13 & 普通食 & - & 断端陽性 & 肺転移死 \\
\hline
\end{tabular}


りの 1 例（症例 7）はその後肺転移をきたし遠隔転移死と なった。症例 13 は原発巣, 頸部再発を認めなかったが肺 転移をきたし, 遠隔転移死となった。 3 年粗生存率は全体 が $92 \%$, T 3 が $100 \%$, T 4 が75\%（図 1)，T3と T 4 で 生存率に有意差は認めなかった $(p=0.13) .3$ 年原発巣頸 部制御率は全体が $83 \%$, T 3 が $75 \%$, T4 が 100\%（図 2), T3 と T 4 で制御率に有意差は認めなかった $(p=0.34)$.

\section{2 喉頭機能について}

普通食の摂取に至らなかった症例は 1 例(症例 4) であっ た. 術後 16 ケ月の時点で軟菜食でも時に誤嬹をきたし, かつ声門狭窄で気管孔の閉鎖困難であったため喉頭全摘出 術を施行した。普通食が摂取可能であるが，十分な食事量 が摂取できず，胃㾞からの補助栄養を捸取している症例が 2 例（症例 $7,12 ）$ あった。気管孔を閉鎖できなかった症例 は 2 例（症例 4,12）認めた。症例 4 は前述のとおりその後 喉頭全摘出術を要した。症例 12 はレテイナを留置されて おり，閉鎖できない理由は新声門狭窄による呼吸困難で あった. 3 年喉頭機能温存率は全体が $76 \%$, T 3 が $89 \%$, T4 が50\%（図 3)，T3 と T4 で温存率に有意差は認めな かった $(p=0.10)$.

3 放射線治療温存について

T3の 2 例（症例 8,9）と T4の 2 例（症例 10,11）が原発

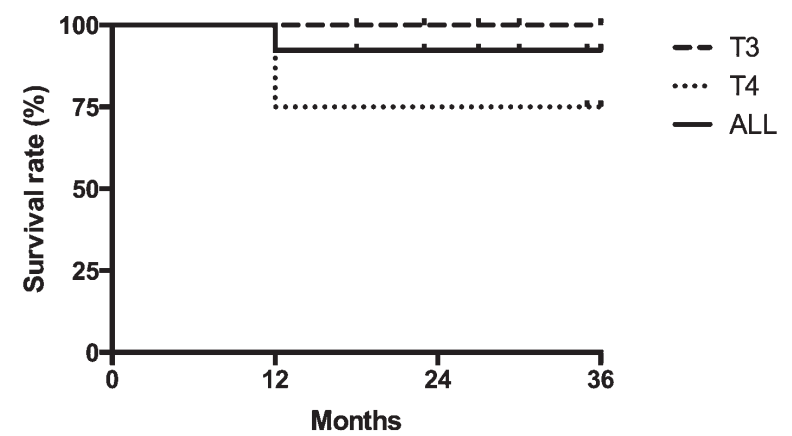

図 13 年粗生存率 $\mathrm{T} 3 \mathrm{n}=9 \mathrm{~T} 4 \mathrm{n}=4$ 全体 $\mathrm{n}=13$

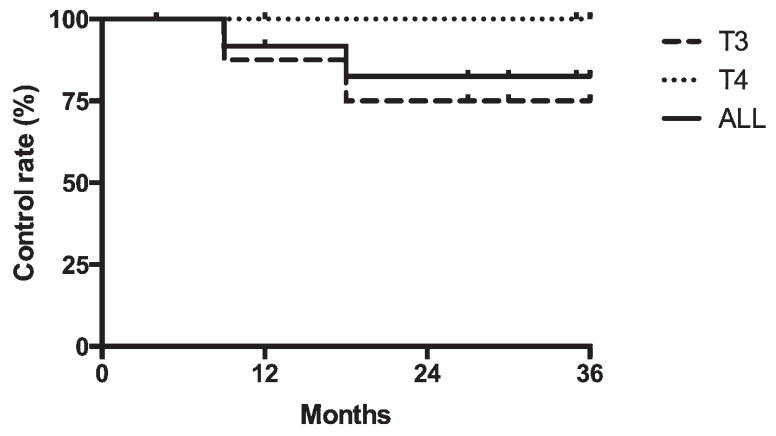

図 23 年原発巣頸部制御率 $\mathrm{T} 3 \mathrm{n}=9 \mathrm{~T} 4 \mathrm{n}=4$ 全体 $\mathrm{n}$ $=13$
巣の切除断端近接, T4の 2 例 (症例 12,13) が断端陽性の ため術後化学放射線療法を施行した。症例 9 は術前検査で T3 と診断した (cT3) が, 摘出標本の病理学的検討では甲 状軟骨の外側を破壊して浸潤する pT $4 \mathrm{a}$ であった。前述の とおり，症例 5,7では頸部再発のためCRTを施行した. 3 年放射線治療温存率は全体が $38 \%$, T 3 が $56 \%$, T 4 が 0\% (図 4)，T3とT4 で温存率に有意差を認めた $(p=$ $0.01)$.

$$
\text { 考察 }
$$

元来局所進行喉頭癌に対しては喉頭全摘出術が施行され てきた。近年 CRTによる喉頭温存の優位性が複数報告さ れ, 初回治療にCRTを施行する症例が増加し, 喉頭全摘 出術を施行する症例が減少している ${ }^{2)}$. しかしその結果と して喉頭癌の治療成績が低下した ${ }^{5)}$ とされ，奏功例でも晚

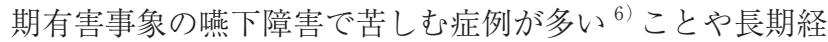
過例では他病死の割合が高い7)ことが問題となっている. それらに加えてT 4 症例では再発率が約 40\%と報告 ${ }^{9)}$ され 満足できる結果が得られていないと思われる。局所進行喉 頭癌に対する喉頭温存治療はCRT以外に喉頭機能温存手 術がある。前方視的試験の困難さからエビデンスレベルの 高い報告は少ないが, 高い治療成績と喉頭温存とCRTに よる晚期有害事象の割合を減らすことのできる可能性があ ると考えられる。本検討では 3 年粗生存率は $92 \%, 3$ 年原

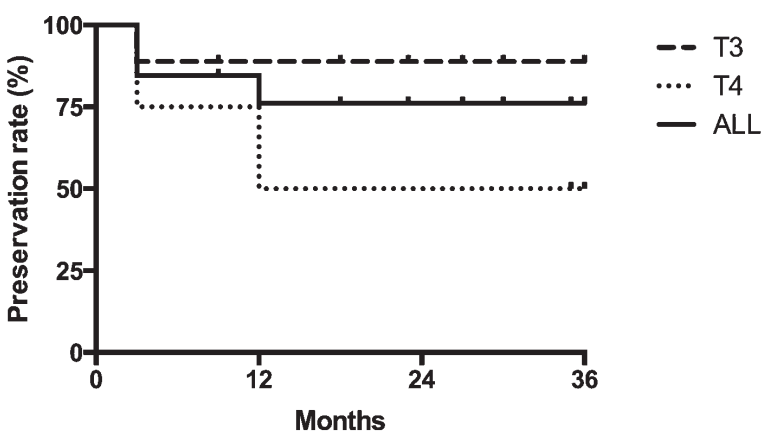

図 33 年喉頭機能温存率 $\mathrm{T} 3 \mathrm{n}=9 \mathrm{~T} 4 \mathrm{n}=4$ 全体 $\mathrm{n}=13$

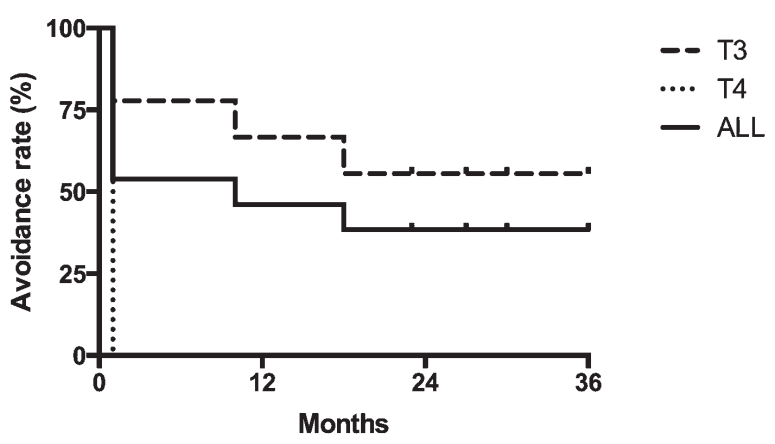

図 43 年放射線治療温存率 $\mathrm{T} 3 \mathrm{n}=9 \quad \mathrm{~T} 4 \mathrm{n}=4$ 全体 $\mathrm{n}$ $=13$ 
発巣頸部制御率は $83 \%$ と非常に良好な結果であった。た だしT $3 \mathrm{~N} 0$ が 7 例 (53\%) と進行喉頭癌の中でも予後良好 と思われる症例が多くを占めており， T4 や $\mathrm{N}+$ 症例を増 やして再度検討する必要があると思われた. Bussuら ${ }^{10)}$ は 進行喉頭癌に対して喉頭全摘出術と喉頭亜全摘出術と CRTを比較している，治療成績は 3 群同等で，喉頭温存 率は喉頭亜全摘出術群が有意に高かった，ただしcT4aに 限れば喉頭全摘出術群の 3 年粗生存率が $78 \%$ と最も良好 で，次に喉頭亜全摘出術群が $68 \%$, CRT群が 54\%の順で あったと報告している。この結果からも T4a症例に対し て安易に喉頭温存治療を锥めるべきではないと考えられ る。しかし喉頭温存を強く希望した場合，喉頭亜全摘出術 の適応となる進展範囲であればCRTより良好な結果が得 られる可能性が高いと考えられる. 当科の検討でも症例数 が少ないが $\mathrm{T} 4$ 症例に術後 $\mathrm{CRT}$ を追加することで全例原発 巣，頸部再発をみとめず， 3 年粗生存率 $75 \%$, 喉頭機能温 存率 $50 \%$ と良好な結果であった，T4に対しても超選択動 注併用放射線療法を行うことで高い喉頭温存が可能との報 告はある ${ }^{11,12)}$ が一般的ではなく, 標準治療となるには至っ ていない.

喉頭温存率を検討した報告は多いが，その多くは解剖学 的な喉頭温存で, 解剖学的喉頭温存と喉頭機能温存は区別 されるべきである，喉頭機能温存の判断に重要な要素は発 声と通常食が可能でかつ気管孔が開存していないことであ り,これらの機能を消失していれば喉頭機能温存とはいえ ない. Benitoらは喉頭亜全摘術後の誤嚥を伴わない正常四燕 下は $60 \%$ であた ${ }^{13)}$ と報告している。比較項目の違いか ら単純比較は困難であるが本検討では $76 \%$ (10 例 / 13 例) の症例で普通食が可能でかつ補助栄養が不要であり, 良好 な結果と思われた。今回，喉頭覀全摘出術だけでなく拡大 喉頭亜全摘出術で摘出した症例も含まれている。拡大喉頭 亜全摘出術による術後嚥下機能については 60 歳代前半ま での症例で拡大切除範囲が 1 方向にとどまっていれば通常 食を摂取可能 ${ }^{8)}$ と報告されている。気管孔閉鎖率に関して Clayburgh らは喉頭严全摘出術後の $11 \%$ の患者に気道拡張 術を施行し，最終的に $95 \%$ 症例で閉鎖が可能であっ た ${ }^{14)}$ と報告している。本検討では $85 \%$ （11例／13 例）に 閉鎖が可能であった，気道拡張術は当科では施行して扮ら ず，今後喉頭機能温存率を高めるためには検討すべきと考 えられた。

局所進行喉頭癌に対して放射線治療温存率を検討した報 告は我々が渉猟した範囲では認めなかった。CRTに伴う 晚期有害事象を避けることが可能で，また重複癌が多い喉 頭癌患者にとって放射線治療のオプションが残っているこ とは非常に有用と思われる。本検討ではT3の55\%に回避 可能であったが，T4では全例に術後化学放射線治療を要 した，CRT後の長期経過で燕下障害をきたしている症例 が多い ${ }^{6)}$ ことと同様に，本検討の喉頭機能温存手術後の患 者が，将来的に嚥下機能が低下することは考えられ，長期 の経過観察を行って検討すべき課題と考えられた。

\section{ま と め}

局所進行喉頭癌に対する喉頭機能温存手術の治療成績に ついて検討した。 3 年粗生存率は $92 \%, 3$ 年原発巣頸部制 御率は $83 \%, 3$ 年喉頭機能温存率は $76 \%, 3$ 年放射線治療 回避率は $38 \%$ であった。 T3 症例に対しては喉頭機能温存 と放射線治療温存の両立が可能であった。 $\mathrm{T} 4 \mathrm{a}$ 症例に対し ては喉頭機能温存手術と術後化学放射線療法を施行するこ とで, 治療成績を落とさずに喉頭機能温存ができる可能性 が示唆された。

本論文の要旨は, 第 27 回日本喉頭科学会 (2015 年 4 月, 東京)で口演した。

利益相反に該当する事項はない，

\section{参 考 文 献}

1) National Comprehensive Cancer Network. The NCCN Clinical Practice Guidelines in Oncology Head and Neck Cancers. (Version 1. 2015). http://www.nccn. org/professionals/physician_gls/f_guidelines.asp. Accessed August 14, 2015.

2) Chen AY, Fedewa $S$, Zhu J : Temporal trends in the treatment of early- and advanced-stage laryngeal cancer in the United States, 1985-2007. Arch Otolaryngol Head Neck Surg 137 : 1017-1024, 2011.

3) Induction chemotherapy plus radiation compared with surgery plus radiation in patients with advanced laryngeal cancer: The Department of Veterans Affairs Laryngeal Cancer Study Group. N Engl J Med 324 : 1685-1690, 1991.

4) Forastiere AA, Goepfert H, Maor M et al : Concurrent chemotherapy and radiotherapy for organ preservation in advanced laryngeal cancer. N Engl J Med 349: 2091-2098, 2003.

5) Hoffman HT, Porter K, Karnell LH et al : Laryngeal cancer in the United States : changes in demographics, patterns of care, and survival. Laryngoscope 116 : 1-13, 2006.

6) Machtay M, Moughan J, Farach A et al : Hypopharyngeal dose is associated with severe late toxicity in locally advanced head-and-neck cancer: an RTOG analysis. Int J Radiat Oncol Biol Phys 84 : 983989, 2012.

7) Forastiere AA, Zhang Q, Weber RS et al : Long-term results of RTOG 91-11 : a comparison of three nonsurgical treatment strategies to preserve the larynx in patients with locally advanced larynx cancer. J Clin Oncol $31: 845-853,2013$.

8）岩江信法, 平山裕次, 古川竜也ほか：術後嚥下機能か らみた拡大喉頭亜全摘出術による喉頭温存の切除限 界. 喉頭 $26: 22-27,2014$. 
9) Rosenthal DI, Mohamed AS, Weber RS et al : Longterm outcomes after surgical or nonsurgical initial therapy for patients with $\mathrm{T} 4$ squamous cell carcinoma of the larynx: A 3-decade survey. Cancer 121 : 16081619, 2015.

10) Bussu F, Paludetti G, Almadori G et al : Comparison of total laryngectomy with surgical (cricohyoidopexy) and nonsurgical organ-preservation modalities in advanced laryngeal squamous cell carcinomas: A multicenter retrospective analysis. Head Neck 35 : 554 561, 2013.

11）横山純吉, 古川 仍：超選択動注療法による局所進行 喉頭癌（T3,T4）の機能温存療法. 日気食会報 60 : 93-99, 2009 .
12) Yoshizaki T, Kondo S, Wakisaka N et al : Concurrent intra-arterial chemotherapy and radiotherapy for advanced laryngeal cancer. Ann Otol Rhinol Laryngol $118: 172-178,2009$.

13) Benito J, Holsinger FC, Pérez-Martín A et al : Aspiration after supracricoid partial laryngectomy: Incidence, risk factors, management, and outcomes. Head Neck 33 : 679-685, 2011.

14) Clayburgh DR, Graville DJ, Palmer AD et al : Factors associated with supracricoid laryngectomy functional outcomes. Head Neck 35 : 1397-1403, 2013.

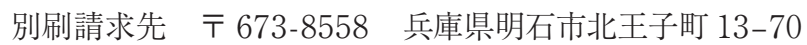
兵庫県立がんセンター頭頸部外科 松居秀敏 